\title{
'The Electronic City, Smart Urban Growth and the Barriers against Realization of it in Iranian Cities' [Case Study: Dezful City]
}

\author{
Professor Dr. Sorush Niknamian
}

Board Member of Weston A Price Foundation, Washington DC, USA

Email: so.niknamian@gmail.com

\begin{abstract}
The ever-increasing expansion of cities, reduction of natural resources, traffic density and congestion are only some of destructive effects left by inadvertent growth of population and related irrational expansion on natural and cultural environments of the communities. Smart growth, is opposed to extensive city growth, emphasizes in city-dwelling and urbanism to create viable communities, proximity to nature and perseveration of open spaces and valuable lands, survival and revival of city center and restriction of suburban growth of city and reduction of reliance on personal vehicle etc. in order to decrease consequences and problems caused by horizontal city growth as mentioned above.

The methodology of this study is of descriptive-analytical type and data collection was done by librarian and documentary technique. This study aims to review and recognize and interpret smart city growth patterns and to identify the existing barriers in Iranian cities and to explore status quo of Dezful city in terms of physical development and horizontal expansion of the given city and to determine rate of compliance of feature of this city to smart city growth patterns. The results of this investigation suggest that despite of having potential capacities to achieve growth of a smart city and lack of preparation of the suitable grounds for this ideal, Dezful city has been remarkably subject to horizontal expansion and it had very poor smart city network compared to the medium-size and developed cities of the world.
\end{abstract}

Keywords: Smart city, Growth of smart city, Dezful

\section{Introduction}

The vertical growth of city is a phenomenon which has occurred not only in developed countries but also in developing nations in the recent half of century. It is called sprawl which refers to a type of suburban expansion of city with the negative consequences Batisani and Yarnal, 2011). The urban expansion form or horizontal expansion of new constructions surrounding the city has led to socio-economic damages and destruction of environmental resources around the cities (Kiani \& Raeisi, 2017). One can refer to some of consequences and problems of inadvertent horizontal expansion of city such as destruction of local communities, social segregation, rise of cost for urban infrastructures and services, increased length and distance of urban trips, rise of energy consumption, high cost for execution of urban transportation system, increase in gasoline consumption, further dependency on using personal automobiles in urban trips, changing use of productive farming lands and gardens surrounding city, air pollution, destruction and contamination of water supplies etc. where all these constraints and problems are assumed as barriers against sustainable urban 
development. This point should be considered of course that presently the cities consume $57 \%$ of total world energy and produce great volume of wastes (Ferraro, 2013) and 52\% of dissemination of greenhouse gases originate from cities (Colldahi et al., 2013).

One of the new concepts for tackling with the current challenges in cities on urban planning scene is development of smart city that has drawn a lot of attention in recent years. Smart growth, which is opposed to extensive city growth, emphasizes in city-dwelling and urbanism to create viable communities, proximity to nature and perseveration of open spaces and valuable lands, survival and revival of city center and restriction of suburban growth of city and reduction of reliance on personal vehicle etc. in order to decrease consequences and problems caused by horizontal city growth. As it mentioned, the effect of dense urban structures during a trip and dependency on vehicle is controversial (Christensen, 2013). Therefore, 'smart growth' is deemed as one of the ways to tackle with expansion of urban development; in fact, the smart growth is considered as an alternative for expansion. The urban sprawl takes place when natural and or farming lands in suburban areas of cities are more quickly moved toward construction than population growth (Azani \& Parvaresh, 2018).

The smart city serves as the given change and development axis and denotes opening new concepts in urban planning which combines potentials of real and virtual worlds together to solve the urban problems. In this sense, it has been tried in this paper to interpret theoretical concepts, characteristics, patterns and challenges to which Iranian cities are exposed in order to realize smart cities and these items have been explored and reviewed in two sections. The first section tends to propose smart growth strategy including planning principles and solutions and recognition of the existing barriers and problems in Iranian cities to achieve smart urban network and globalization of cities. In the second part, this paper has determined position of Dezful city by analysis of findings and comparing them with the patterns and standards of smart growth.

\section{Research objectives}

Some of main goals of this study include analysis, recognition and interpretation of patterns of smart city growth and identifying the existing barriers in Iranian cities against the balanced development and accomplishment of standards of smart city. In this regard, For example it has been discussed about the current position of Dezful city in terms of physical development and horizontal expansion of the given city and determination of rate of compliance of features of this city with growth patterns of smart city.

\section{Methodology}

The present research is an applied study in terms of objective and documentary-librarian type in terms of way of data collection. Geographic Information System (GIS) software has been also utilized to prepare roadmap. The statistical population of this study also includes Iran and Dezful city at lower level. All of available information and statistics have been extracted from leading international websites and statistical centers.

\section{Research literature}


The focus and paying attention to urban cores are very slightly visible for the first time in works of Harris and Olman throughout the world where they emphasized in city growth by modeling theories of precedent scientists with a predetermined framework (Farid, 1994: 145147).

More simply, 'smarting' means potential for learning from and about environment and perception and interaction with it in line with adaptation to the new environment and the exerted changes in current environment (Chourabi, 2012). In 1990s, concept of smart growth appeared following to growth management subjects that had been employed in planning system in 1970s and 1980s. The smart growth has emerged as a response to duration of dispersive development problems and the negative consequences and included different and numerous historical references that dated back to the previous decades out of which one can refer to planning efforts for use of national lands, state growth administration rules and change in planning for housing and the like (Edwards \& Haines, 2007: 49). International Association for Urban Administration proposes a comprehensive of smart growth as follows: This development covers economy, community and environment and prepares a framework for communities by which decision making is formed to determine where and how the growth takes place (Heidari Soureshjani \& Khalaji, 2018). Although smart growth is deep-rooted, in this regard one can refer to some influential studies about pervasiveness of this model in other points of the world including:

1. Smart growth message and local preservation law in Maryland: This law entered political scene in Maryland in 1997 and it aimed at creation of purposive development in preferred areas for investment, protection from rural lands, encouraging for redevelopment of constructed areas and proximity of workplaces and living areas and the like.

2. Publishing of legal guide for smart growth: This book belongs to American Planning Association (APA) and it is the outcome of the activities which have started in this association since 1994 and it was published in 2002. This book is a guide for updating land use control and allows the planner to identify better the problems of using up the sources, traffic problems and shortage of available housing (Daniels, 1997:16).

3. Publishing a paper as an introduction to smart urban growth: This paper has been published by Dr. Keramatollah Ziari who tried to identify the patterns of smart urban growth along with publication center of organization of municipalities in 2012.

4. Publication of paper concerning evaluation of pattern of smart urban growth in Iranian new cities focusing on Sadra New City: The author has determined position of spatial performance in formation of Sadra New City regarding patterns of smart urban growth in this paper.

5. Zeynali and AghaJani (2014) carried out an investigation titled 'Smart urban growth as a requirement in cities in the third millennium' that referred to inadvertent, dispersive and uneven growth of cities, especially in third world countries and it has created several environmental problems for urban administration and planning and it will mainly affect uneven and hideous urban development as the marginalized zones with non-standard 
infrastructures that may lead to social conflicts and emerging of cultural problems (Zeynali and AghaJani, 2014).

The distinct difference of the current research from other conducted studies lies in comparison of urban sprawl and smart growth in line with sustainable development in Isfahan city Region No 11 and it has been shown that it can be moved by optimal exploitation from the spaces and planning system toward smart growth and lack of dispersed expansion of this region and this step can be taken to pass through dispersive and horizontal pattern toward smart growth in the course of integrate urban growth at this region (Zeynali and AghaJani, 2014).

6. In a paper under title of 'Could smart growth reduce operational energy of water supply? Analysis on scenario in Tampa at Florida, USA' in 2018 written by Marc V. Santana et al., it has been mentioned that the cities have been exposed to more pressure for minimization of energy consumption and dissemination of greenhouse gases. As a result, the useful drinking water should be able to improve efficiency of the related managerial systems and consequently to guarantee for clean wastewater that could meet standards of drinking water. A possible solution may be a paradigm of urban development by aiming at reduction of environmental consequences of urbanism through smart growth. Thus, this study has been conducted to determine effect of smart growth on energy of performance of distribution of drinking water. The measurement of drinking water services has been used in water project based on several urban growth projects. Then, the predicted water consumption in any scenario has been integrated in EPANET simulation of Tampa water distribution system for the next estimation of operational energies of distribution of drinking water. The results indicate that the smart growth has not uniquely influenced in operational energy of water supply. Nevertheless, the added application site has not affected operational energy than water treatment installation site. Similarly, the smart growth in urban services zone in Tampa city reduced $6 \%$ in water consumption and decreased energy consumption 6-10\% and up to 2.6-5.5\%. As a result, smart growth in the zones near to water treatment facilities may contribute to reduction of energy consumption relating to water (Santana et al., 2017).

7. In another survey which was conducted by Ahmad Pourahmad et al. under title of 'Explanation of concept and properties of a smart city', the findings indicated that despite the extensive literature about concept of smart cities, there was no clear and unanimous perception of this subject and various academic researchers have presented different suggestions so that some of smart technologies have been assumed as the only or the least part of smart city. Some other researchers suggested that it might be beyond the high technology and believed acceptance of the technology was not the end point. Technologies may be utilized in cities in order to improve citizens by adjusting this technology to their requirements instead of adaptation of life to technological needs. In addition, concept of a smart city is a multifaceted subject. The key point les in this fact that the cities should respond to the changes exerted to them in this field. Moreover, the quality of something that should be considered as smart nature depends on various types of basic conditions e.g. political 
system, geography and distribution of technology. In fact, one could not copy smart solutions; therefore, any field should have different value (PourAhmad et al., 2018).

\section{Definitions and concepts}

Urban city (namely, changing of land use concerning residential, commercial or industrial development) is an important incentive to change landscape in many points in the world and it is the main origin for permanent changes in landscape and destruction of habitats in most of these points which may influence in health of both of environmental systems and potential of landscape to protect from biological diversity (MacGarigal, et al., 2017). Human habitats affect natural vegetation and structure and performance of ecosystems so that over 200 years ago, world population has approximately increased 6 times and in addition to important social and economic challenges, growth of urbanism spaces may exert high pressure to many ecological properties e.g. water brooks, forests and atmosphere and other ecosystems (Marinoni et al., 2018). This has made requirement of formation of new urban points as inevitable within the framework of cities that lack problems of former cities, particularly regarding smart services and growth (Stalker, 2000:16). Inter alia, smart city is an applied term for expressing urban activities with information and communication technological infrastructure and it is not assumed as unreasonable that the achievement of smart city has been deemed as the foremost mid-term goals for them based on many available investigations and reports in advanced countries (European Parliament, 2014; Giffinger et al., 2007; Pichler- Milanovic, 2005; Pazalos, 2012). The presence of internet in USA Department of Defense started sine early 1960s and it was developed by cooperation with University of California in 1969. The civilian activity of internet practically started by electronic mail service (email) in 1983 and this potential was more quickly provided in data transmission. In the mid-1990, 46000 information networks could exchange data throughout the world including 2.3 million pcs with 25 million users via internet. The comparison of above-said figures with requirements of an electronic city may indicate that by this time, technological facilities could not exist practically to establish electronic city, but statistics of UNESCO Message Quarterly showed the latest numbers of internet users 655 million in the world in October 2003.

While in its latest statistics about world internet users by the end of 2007, Internet World Stats has divided number of internet users into 7 groups based on geographical situations and it announced number of users 1 billion and 319 million in the world. The noticeable point is the speed of developing elements of this phenomenon e.g. communication and information technology which has led human's traditional life gradually to the amazing position called electronic life and transformed economic, social and political dimensions. Therefore, symbiosis and community are some of requisites for communication as the primary principles of comprehensive information that is shown in a place called electronic city. The electronic city is a place where activities of citizens are managed including public services and organizations of private sector online and round-the-clock and seven days of a week by high quality and security level and by exploitation from Information Technology and 
Communication (ITC) and related applications. Many other definitions have been proposed for electronic city some of which are as follows:

1- Electronic city is called to a place for employing ITC in giving social, administrative and economic services, especially in urban sector to enhance productivity as well as improvement of services and proposing information to the citizens.

2- The electronic city is called to a site for using technology to put more efficiently urban services and information at disposal of citizens and merchants etc.

3- Electronic city denotes a group of activities by which urban services are proposed electronically to the users and the information is exchanged by users of these services via internet.

The electronic city will exit us from one-dimensional world of traditional and today cities and lead us to a new world; a 2-dimensional world that is the achievement of modern ITC technologies. Over the time and in moving our technology forward, we will witness a tridimensional world in near future that it is impossible for us even to imagine it at present. Many activities which are done in normal cities can be implemented and performed in electronic city and one can imply it explicitly such activities will be much easier in electronic cities than their physical examples (http://www.ayandehnega.org).

\section{Electronic city:}

Term of 'electronic city' was introduced for the first time by Muschwitz in 1986. Malon and Davido were the first ones who precisely and duly proposed idea of 'electronic business' in their book. The electronic city covers wide range of organizational economic and noneconomic activities. The electronic business includes working at home, small- and mediumsized electronic businesses to great business networks within domain of economic activities. On the other hand, electronic city has also wide use in other sectors especially in cooperation among scientific institutes, civilian and non- governmental groups and city. Following to developing computer and IT, electronic city was posited as a type of organization. Electronic city is composed of geographically dispersed organizational, semi-independent and semipermanent units which have developed their organizational forms by their general performance to meet the market requirements and ITC technological potentials through continuous adaptation. The business operation and products processes have been dispersed in various confederate enterprises in electronic city. These various enterprises from different countries have been distributed as common wealth form by very close cooperation with each other. The electronic city has been created from various independent enterprises where these enterprises may jointly use their main competitive advantages to win in great market of opportunities. Electronic city should be founded on computer and network systems. ITC technology prepares the software platform for electronic city. The activities of enterprise are mainly shown in electronic city based on ITC platform by conversion of data and files inside the network e.g. face-to-face communication. The frequent data flow will be the major task of communication in electronic city instead of real product of enterprises in traditional operation (Protecting America's farms Ebbers, 2007: 128). 


\section{Landscape of electronic city}

The electronic cities in the world possess various landscapes based on their positions, facilities and national and international potentials and views. For example, we will examine landscapes of Brisbane electronic city in Australia and Durban city in South Africa as two completely different types in terms of facilities, potentials, demographic composition, economic status and development level.

\section{1) Brisbane}

Brisbane is located in the capital of Queensland State and assumed as the third large city in Australia with approximately one million people population and it is among the 25 superior cities of the world in terms of quality of life. Based on outlook document of life in Brisbane in 2010 which was published by city council of this town in 2000, eight strategic outlooks were designated for Brisbane electronic city as follows:

a) Green and clean city

b) Accessible city

c) City designed for appropriate life

d) Smart and thriving city

e) Creative city

f) Comprehensive and pervasive city

g) Healthy and active city

h) Typical city in the region and world (Odendaal, 2003: 596)

\section{2) Durban}

Durban city is located on eastern beach of south Africa in Kwa-Zulu-Natal State. With population of one million, this city is various in terms of culture and economy. About $23 \%$ of population lives in absolute poverty in this city and only $38 \%$ of youths passed high school education. Despite all these conditions, twenty-year outlook plan has been designated for this city to management and making decision in this electronic city. The outlook of Durban electronic city includes the followings:

a) Economic growth and entrepreneurship

b) Providing for basic needs

c) Reduction of poverty

d) City development and human resources development

e) Creation of safe and secure environment (Nazari \& Aghazadeh, 2009:8)

\section{Model of electronic model}


The electronic city is composed of various parts and elements in which the deliberative interaction between them enables living in knowledge-based environment. Absence of each of these factors may expose electronic city to major problems. Several models have been so far presented for electronic city and it has been tried in these models to draw a general image of what takes place in electronic city (Pour Ahmad et al., 2010:107).

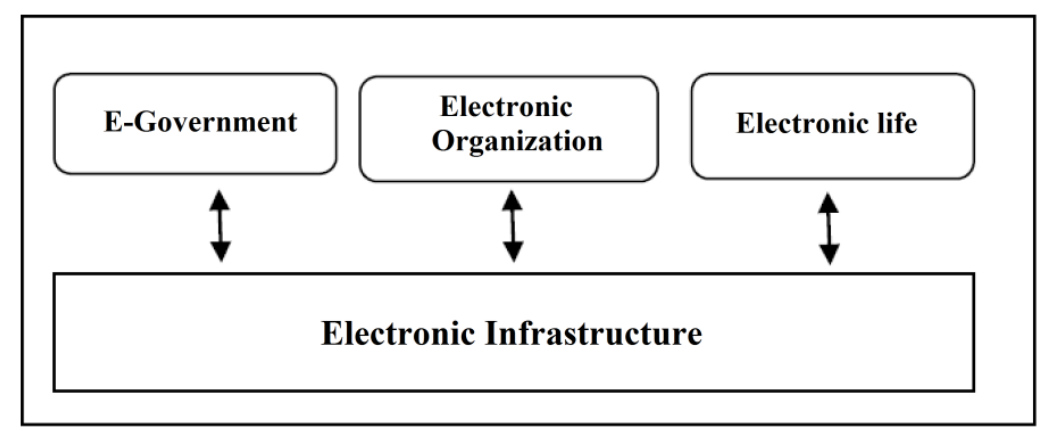

Fig 1: The given model of electronic city in Conference of Electronic City in Taipei (2002)

Source: Hari Tokyo Institute of Technology (Tokyo, 2002)

\section{Some of activities in electronic city}

1) Banking activities: e.g. receipt payment, withdrawal from account, money transfer etc.

2) Administrative activities: Such as registration of documents and properties, application for passport etc.

3) Commercial activities: For example, goods purchase and sale, music, movie and foods ...

4) Recreational activities: e.g. computer games, visit from museums and parks etc.

5) Acquisition of information: News, newspaper, journals, urban traffic, flight clocks for airplanes ...

6) Scientific activities: Research on projects, paper finding, access to reliable sources and digital libraries etc.

7) Educational activities: School and university and other educational centers

8) Political activities: Participation in elections, commenting to parliament and open political sectors etc.

9) Travelling activities: Booking for trip ticket and reservation of hotel via internet etc.

10) Job-finding and business application: Being aware of job opportunities, filling out application form, transmission and receiving results etc.

11) Decision-making activities: The best and most vacant route to reach destination in city (Sahu, 2007:236)

\section{Urban smart growth}

The smart growth is assumed as a reaction to expansion. The expansion has been criticized because of rising costs of housing, high density of traffic and creation of infrastructural and 
unnecessary costs while smart growth aims to balance needs of individuals with economic development jobs. The major differences have been compared between two land use patterns in Table (1).

The smart growth is a tool-centered concept for which there is no agreement over related definitions, but supporters of smart growth agreed unanimously over ten principle of this concept by USA Environmental Protection Agency.

\section{Ten principles of smart city}

$\checkmark$ Creation of mixed uses;

$\checkmark$ Emphasis in advantages resulting from design of dense buildings;

$\checkmark$ Providing various alternatives for selection of housing;

$\checkmark$ Creation of localities with pedestrian access;

$\checkmark$ Distant and attractive localities with high sense of identity;

$\checkmark$ Protection from open spaces, farming lands, beautiful nature and environmental zones;

$\checkmark$ Improving development for the existing communities;

$\checkmark$ Providing variety of transportation choices;

$\checkmark$ Predictable developmental decision making;

$\checkmark$ Encouragement of communities and beneficiaries for participation in development

The smart growth is assumed as a reaction to expansion (sprawl). The expansion has been criticized because of rising costs of housing, high density of traffic and creation of infrastructural and unnecessary costs while smart growth aims to balance needs for individuals with economic development jobs (Peiser, 2001: 277-278). The major differences have been compared between two land use patterns in Table (1).

In addition to intensive form of city, in fact smart growth emphasizes in optimal use from urban spaces to establish communities with pedestrian access. Of course, some people disagree with this idea and they argue smart growth is not too stable. Similarly, while smart growth network has identified environmental protection and preservation and biological diversity as one of ten leading factors of smart principles, those methods are not adequate for combination of these values in planning process of land use (Underwood et al., 2018). Table (1) shows difference of smart growth strategies and dispersive growth in urban development.

Table 1: Difference of smart growth strategies and dispersive growth in urban development

\begin{tabular}{|c|c|c|}
\hline Index & Smart growth & Dispersive expansion (sprawl) \\
\hline Density & Intensive development & Low density, dispersive activities \\
\hline Growth pattern & Inter-texture development & Surrounding development \\
\hline Mixed use & Use of mixed lands & $\begin{array}{c}\text { Homogeneous land use (separate and } \\
\text { one-functional uses) }\end{array}$ \\
\hline Scale & $\begin{array}{l}\text { Hunan scale, smaller buildings, } \\
\text { blocks and roads }\end{array}$ & $\begin{array}{l}\text { Large scale, large buildings and blocks } \\
\text { and wide roads }\end{array}$ \\
\hline $\begin{array}{l}\text { Public services (shops, } \\
\text { schools and parks) }\end{array}$ & $\begin{array}{l}\text { Local, smaller and based on } \\
\text { pedestrian access }\end{array}$ & $\begin{array}{l}\text { Regional, integrate, greater- need to } \\
\text { access automobile }\end{array}$ \\
\hline Transportation & $\begin{array}{l}\text { Presentation of various } \\
\text { transportation modalities and } \\
\text { land use patterns in which }\end{array}$ & $\begin{array}{l}\text { Automobile- based transportation and } \\
\text { land use patterns are not too efficient }\end{array}$ \\
\hline
\end{tabular}




\begin{tabular}{|c|c|c|}
\hline & $\begin{array}{l}\text { walking and bicycle-running are } \\
\text { considered }\end{array}$ & $\begin{array}{c}\text { for walking and bicycle-running and } \\
\text { transit. }\end{array}$ \\
\hline Communications & $\begin{array}{l}\text { Roads, walks and extremely } \\
\text { connected routes together enable } \\
\text { guiding of motorized and non- } \\
\text { motorized trips. }\end{array}$ & $\begin{array}{l}\text { The hierarchical road- network with } \\
\text { numerous loo[s and endless streets, } \\
\text { disconnected paths and walks, the } \\
\text { existing barriers against non-motorized } \\
\text { trips }\end{array}$ \\
\hline Design of street & $\begin{array}{c}\text { The streets have been designed in } \\
\text { compliance with various } \\
\text { activities (reducing traffic } \\
\text { volume) }\end{array}$ & $\begin{array}{l}\text { The streets have been designed to } \\
\text { increase traffic speed and volume of } \\
\text { motorized vehicles. }\end{array}$ \\
\hline Planning & Planned & Unplanned \\
\hline Public space & $\begin{array}{c}\text { Emphasis on public field } \\
\text { (environment of walks, parks and } \\
\text { public facilities) }\end{array}$ & $\begin{array}{l}\text { Focus on private field (yards, shopping } \\
\text { centers, indoor and closed spaces, } \\
\text { private clubs) }\end{array}$ \\
\hline
\end{tabular}

Source: Victoria transport policy institute (2005)

\section{Barriers and problems against realization of smart city in Iranian cities}

- Competitiveness and lack of identical potential of cities for competition at world scale with respect to global continuity of cities

What it clear is that the globalization literature is passed through primary stages in Iran but the speed of spreading of this literature is growingly increased so that out of totally 19 important references which have been published from 1991 to 2006 in Iran including written and translation books and papers, only 79\% of them have been printed since 2001 and this indicates lack of globalization measurement techniques of countries especially in publication of references. Analysis on globalization trend in cities will be a difficult task regardless familiarity with globalization trend at national macro level because cities are under influence of national system and they are also subject to changes in general system as well. Thus, globalization of cities has been analyzed in this section. The globalization term might have been used for the first time by Scottish sociologist, Patrick Geddes in 1915. This term refers to expanded cities into new wider groupings or Ecumenopolis.

\section{Position of Iran in terms of globalization index}

The position of Iran has been characterized for five years based on globalization index (A.T. Kearney) in Table (2) between 62 countries of the world. The basic point is that during years, Iran has been placed at the lowest level. This condition is also visible in Diagram (1) clearly.

Table 2: Position of Iran in globalization index

\begin{tabular}{|c|c|c|c|c|c|c|c|c|c|}
\hline \multicolumn{2}{|c|}{$\begin{array}{c}\text { Globalization } \\
\text { index 2001 }\end{array}$} & \multicolumn{2}{c|}{$\begin{array}{c}\text { Globalization } \\
\text { index 2002 }\end{array}$} & \multicolumn{2}{c|}{$\begin{array}{c}\text { Globalization } \\
\text { index 2003 }\end{array}$} & \multicolumn{2}{c|}{$\begin{array}{c}\text { Globalization } \\
\text { index 2004 }\end{array}$} & \multicolumn{2}{c|}{$\begin{array}{c}\text { Globalization } \\
\text { index 2005 }\end{array}$} \\
\hline $\begin{array}{c}\text { Ran } \\
\mathrm{k}\end{array}$ & Country & $\begin{array}{c}\text { Ran } \\
\mathrm{k}\end{array}$ & Country & $\begin{array}{c}\text { Ran } \\
\mathrm{k}\end{array}$ & Country & $\begin{array}{c}\text { Ran } \\
\mathrm{k}\end{array}$ & Country & $\begin{array}{c}\text { Ran } \\
\mathrm{k}\end{array}$ & Country \\
\hline 1 & Singapore & 1 & Ireland & 1 & Ireland & 1 & Ireland & 1 & Singapore \\
\hline 2 & $\begin{array}{c}\text { Netherlan } \\
\mathrm{ds}\end{array}$ & 2 & $\begin{array}{c}\text { Switzerlan } \\
\mathrm{d}\end{array}$ & 2 & $\begin{array}{c}\text { Switzerlan } \\
\mathrm{d}\end{array}$ & 2 & Singapore & 2 & $\begin{array}{c}\text { Switzerlan } \\
\mathrm{d}\end{array}$ \\
\hline 3 & $\begin{array}{c}\text { Sweden } \\
3\end{array}$ & Singapore & 3 & Sweden & 3 & $\begin{array}{c}\text { Switzerlan } \\
\mathrm{d}\end{array}$ & 3 & USA \\
\hline$\ldots \ldots$ & $\ldots \ldots$ & $\ldots \ldots$ & $\ldots \ldots$ & $\ldots \ldots$ & $\ldots \ldots$ & $\ldots \ldots$ & $\ldots \ldots$ & $\ldots \ldots$ & $\ldots \ldots$ \\
\hline
\end{tabular}


The political disputes among Iran and USA and American unilateral sanction and the subject regarding uranium enrichment in Iran and dialogue of European countries with Iran have led to serious problems in foreign direct investment process in this country and caused national economy to take step lamely. The internet limitations have caused reducing technological link among this country and the outside world. The numbers of Iranian security servers are very low per capita and even lesser than Bangladesh. Discontinuity of servers and governmental control over internet users is one of the problems of globalization. According to this report, it is a long time that Iran has been forgotten based on private contacts of its citizens with the rest of world. The ratio of number of tourists to national population is only $7 \%$ and it is even less than Senegal (10.5\%) and in comparison with Saudi Arabia (47.2\%). Clearly, Iran does not proceed quickly in many fields (Ibid). As it also implied at the beginning of discussion, analysis of globalization trend in cities in Iran will not be perceivable without analysis on national trend of globalization. Therefore, any effort made for globalization and trend of globalization in cities requires for adaptation of national system to globalization. Otherwise, no favorable outcome will result.

- The lack of necessary budget for execution of projects of smart cities

- Innovative projects and developments at small scale do not necessarily guarantee for efficient realization of through wider level of city.

- The possibility for failure in investments and ignoring of local requirements and priorities

- Public complex ecosystem, institutions and shareholders necessitate for much efforts to organize and establishment of discipline and order.

- Managerial approaches

- Rejection for cultural attitudes

- Presence of legal problems for urban administration to possess lands

In addition to above-said items, developing of urban textures requires for housing and development in various types of technologies their result has affected living conditions in cities and exposed most of our cities to the crisis. Rising number of automobiles, increase in land and housing price, need to type of public services, human healthcare problems, necessity for execution of varieties of civil activities e.g. expansion of green space, creation or leveling macadamized routes, public and infrastructural utilities and the like are all exposed to several basic factors. These factors include suitable institutional organization, planning, widely employment of expert forces, providing for urban requirements and having adequate budget and finally efficiency of urban administration. In other words, our city have possessed some rules, procedures and regulations regarding urbanism out of which most of them dated back to the decades very long ago when neither was urbanism so wide in Iran, nor did municipalities need to enactment of new urban rules and regulations under their aegis they could appropriately and properly administer the activities of cities by suitable efficiency. Having certain plan, institutional organization, employing expert manpower and providing the needed budgets also require for improvement in urban administration by which they can manage our modern cities well. Under such cases, the country has witnessed that the urban administration is majorly exposed to burden of structural and institutional, expert and 
budgetary problems in managing activities in cities and in light of this bottleneck, problems of our cities not only have not been legally resolved, but also they have wasted their existing potentials and left the problems unsolved (Shia, 2003:39).

Iran has no suitable position in this regard and its position is also in conflict with the national development objectives, especially 20-year outlook plan so that it is farthest from world level in terms of communication index. As a result, improvement of this index is preferred. Thus, this country need to the necessary platforms, especially for developing of the given infrastructures for this activity to enter the field of smart cities in Iran. Dezful is one of Iranian cities that have been subject to such changes.

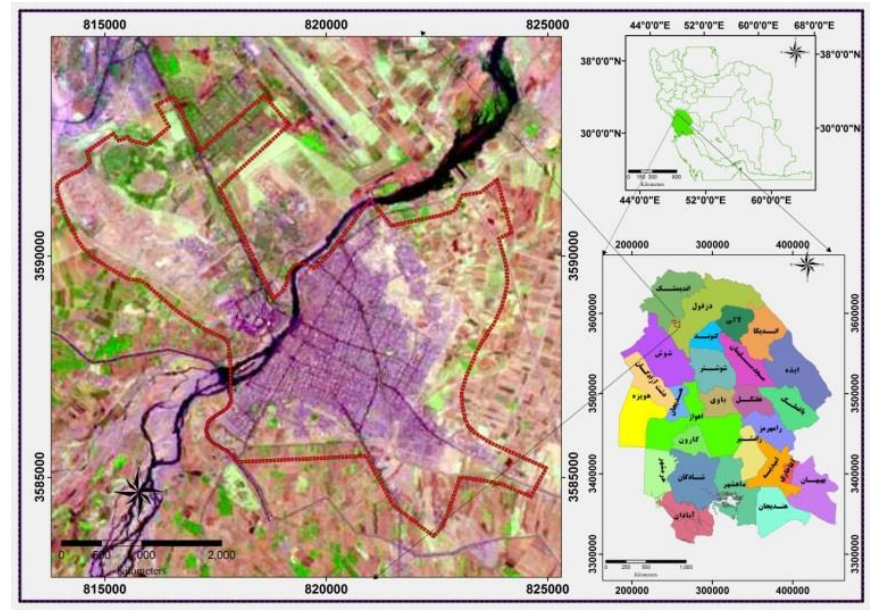

\section{Studied zone}

Dezful is situated at the north of Khuzestan province and its capital. With area of 4'672 $\mathrm{km}^{2}$, this city is located on Khuzestan plateau. This city is placed in a geographical situation among eastern longitude $\left(48^{\circ}, 34^{\prime}\right)$ from Greenwich Meridian and northern latitude $\left(32^{\circ}, 7^{\prime}\right)$ from Equator and it is located $120 \mathrm{~m}$ higher than sea level. Dezful city is limited to Lorestan province from the north, and Shooshtar from the east, Ahwaz from the south, and Andimeshk and Ilam from the west (a report from studies of comprehensive projects for Dezful city, $\mathrm{p}$ 3). According to Public Humans and Housing Census (2011), population of Dezful was 248’380 (Safaeiepour \& Abbasi, 93, p 5). Map No 1 indicates situation of studied zone.

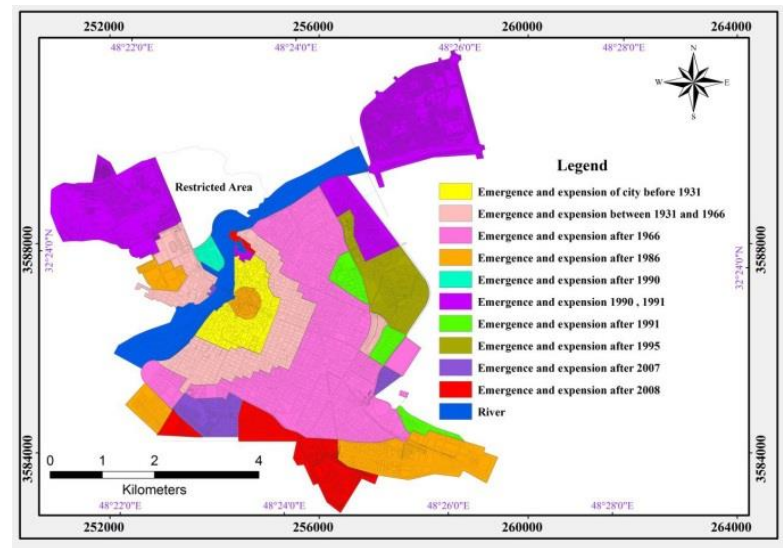




\section{Map 1: The map of position of Dezful city (Source: Author, 2018) Dezful city growth patterns}

In the course of unbridled urban expansion, by taking all-inclusive approach to all development dimensions, the sustainable development and smart growth, proposed to achieve stability, may meet objectives and intentions of modern urbanism. The city structure denotes recognition and organizing relationship between constituent elements of urban spaces and it is deemed as important components for urban design. Similarly, if one can identify the structure of city and plan for it, the other parts will follow this major structure as the lower level of structural and functional hierarchy (Alalhesabi \& Abbasi, 2011: 10-12).

Similar to most of Iranian cities, spatial development trend of Dezful city has been affected by traditional (organic) and modern (inorganic) patterns. From the beginning. The traditional and organic growth pattern was formed within the endogenous development framework slowly and gradually and from the north to the south since the beginning of current century through Pahlavi period and particularly before agrarian reforms. This effect has been exerted mainly as internal flow of city population in response to its growth and content transformation and change in composition of urban elements and the land was adequate for traditional uses and it has organically regulated city space based on economic and social conditions of the city.

The second mode of development pattern is the modern and inorganic development by which this city has been influenced in less than a half of recent century and subjected to several changes by hasty and pervasive modernization and expansion of capitalistic relations in Iran. The physical development of city in this period resulted from the changes that have already occurred in production relations and currently appeared spatially. Also during recent decades, growth has been more seriously discharged outside and symptoms of inorganic growth have been realized so that the area of Dezful city has been increased two times than the past from 1960s to 1990s). the city has been expanded in all directions, especially toward western side of city and residential localities were developed and completed within classic texture. The outskirt settlement is visible particularly in eastern parts due to mass migration and gradually the outskirt regions are connected to main city texture (Babaeifar, 2012:75).

Since 1990s, some new layers were added to the city. City expansion has been mainly extended along with communication routes and as a result physical development of city has led to emerging of new residential regions within two recent decades and Dezful city has witnessed many demographic changes during recent decades. The city growth has occurred at the margin of new streets but the new townships around the city and occurrence of marginal villages within legal limits of city have subsequently intensified city growth. The form of city has been converted from solid and integrated texture to the dispersive texture as the consequence of inadvertent horizontal expansion and in different directions. This trend may be called as internal collapse and external expansion and it has been generally followed by discontinuous and discrete growth of city and disturbed general balance in infrastructural network and urban services. Therefore, Dezful is one of the cities which have been exposed to numerous problems in this regard as the consequence of the given formative-physical 
growth and development for which it will be difficult to accomplish suitable and physical composition of urban space if a specific strategy is not taken in positioning of appropriate lands for future development of city. Map No (2) displays formative development of Dezful city during several years.

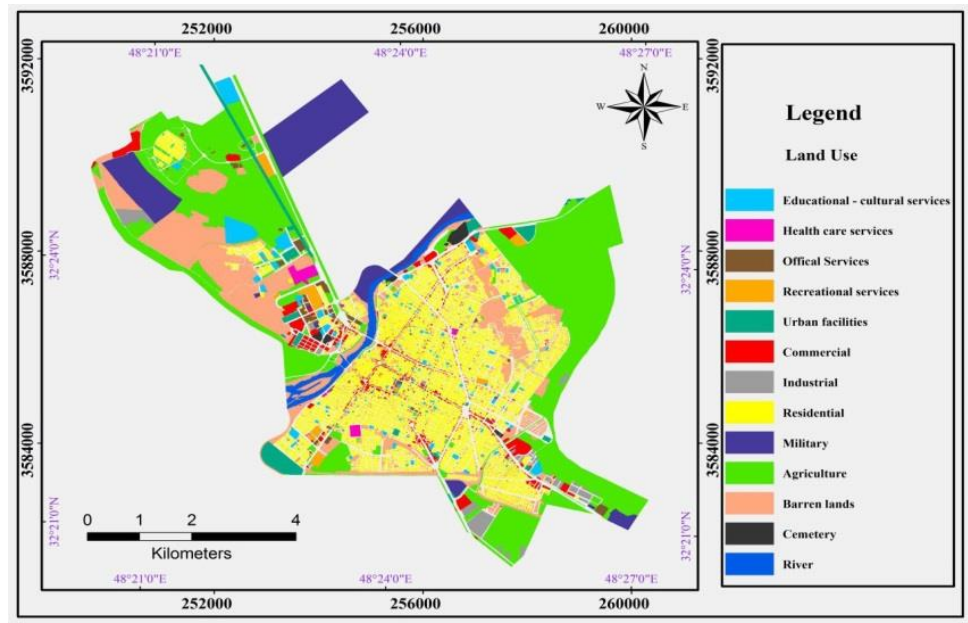

Map (2): Historical development trend of Dezful city (Source: Drawn by author, 2018)

The high potential for receiving population of this region and great susceptibility for framing development along with growth and development of industrial parks and centers have attracted many immigrant population to this city. While the additional servicing and welfare centers and other needed social facilities are not adequately provided for surplus population and for this reason there are some problems and difficulties in giving services that exert pressure to Dezful city.

Some of these demographic and social bottlenecks in this city include currently high rate of population growth of city and potential for receiving immigrant population at high level and consequently social abnormalities in city outskirt regions. There are also some problems concerning formative field such as interference of residential and industrial uses, low quality of buildings in old points of city, inadvertent growth and dispersive and unplanned city expansion, demolition of farming lands due to inadvertent constructions and tendency of city expansion to farming lands, high density of residential uses in newly-constructed parts and lack of coordination of these parts with old texture and eroded infrastructural facilities such as water and wastewater utilities, unsuitable distribution and dispersion of urban facilities and equipment and dispersed and unplanned establishment that are analyzed (Municipality, 2011:15).

\section{Conclusion}

Dispersive expansion of urban zones and numerous economic and ecological consequences have made experts of urban issues to search for finding strategies to tackle with this problem. In this regard, several case and sectional solutions were proposed within recent decades until the last decade of twentieth century when the smart growth was proposed as a comprehensive strategy to tackle with dispersive and sparse expansion of regions surrounding cities and 
employed in many developed nations. The smart growth presents intensive use patterns based on walking and bicycle-running.

The communities of smart growth and modern urbanism tend to the streets with the connections more than classic networks where it is more emphasized further in narrow routes to decrease traffic. In smart growth, social involvement is assumed as necessary and important for expansion of developing and locality relations and it employs spatial planning as a reliable tool versus dispersion from urban density at medium level. Iran is one example of countries that possess poor smart urban network. Demographic developments in our country during recent decades and rising immigration to cities have been followed by quick growth of textures regardless of land use issues, cultural and social characteristics and ecological conditions. Poor administration by municipalities and their weak institutional structure have led municipalities to routinizing trend in taking infrastructural measures and keep them away from developing infrastructural activities in social and economic and formative fields. Inter alia, by identifying barriers and constraints against development of Dezful city and determination of optimal directions for city development, it can be mentioned various regions in Dezful city have been different in terms of development in various fields and in different time periods that indicate lack of coordinated development in various regions of city proportional to their demographic requirements so that the main tendency of city development appears discretely at northwest and northeast of this city. Improvement of more dense settlement pattern in localities surrounding of central texture of city as well as reconstruction and renovation of the old texture may in turn extremely contribute to balancing in spatial organization of city. At the same time presence of arid and deserted lands inside urban limit has also led to waste public capitals rather than creating imbalance development inside city and such inequalities originate from lack of adequate land area, natural and economic factors and also deficiencies in planning system.

Dezful city includes strong and secure infrastructures for urban smart growth. It necessitates constantly for a codified planning to enter the city and by participation of all executive and investment organizations and one can take efficient steps to realize a smart city with respect to useful and effective available infrastructures.

\section{Suggestions}

$\checkmark$ Creation of mechanisms with the mixed uses for localities at suitable scale

$\checkmark$ Proposing some incentives to encourage local communities to rise density

$\checkmark$ Supporting from regional planning efforts to encourage for intensive construction density

$\checkmark$ Preparation of a plan for identifying and reconstruction of the old and deserted buildings

$\checkmark$ Giving financial aid to local communities to improve the existing streets and walks to create pedestrian-centered communities

$\checkmark$ Establishment of basic services near to house, workplace and transportation

$\checkmark$ Further beautification and maintenance of the existing and newly-constructed walks

$\checkmark$ Creation of opportunities for bilateral interaction between localities

$\checkmark$ Definition and determination of visual signs for communities and localities 
$\checkmark$ Widely use of new financial instruments to facilitate keeping outdoor spaces

$\checkmark$ Partnership with non-governmental organizations (NGOs) to preserve the lands

$\checkmark$ Facilitation of a plan to encourage for renovation and reconstruction of houses in the existing localities

\section{References:}

\section{Persian sources}

1. Babaeifar, Atefeh (2012). Analysis on physical development of Dezful city, MA thesis, Ahwaz University of Shahid Chamran.

2. Ziari, Keramatollah (2012). An introduction to theory of urban smart growth. Publication of Organization of Municipalities. 12 $2^{\text {th }}$ year. Vol. 104.

3. Pour Ahmad, Ahmad, Mohammadpour Saber, Mohammad Hossein Bouchani (2010). Review on concept of participation of citizens in activities of electronic city, Scientific- Researching Quarterly of physiography- $2^{\text {nd }}$ year, vol. 4.

4. Municipality, A report of studies on comprehensive project of Dezful city, 2012.

5. Shia, Ismail (2003). Necessity for development in urban administration in Iran, Journal geography and development, spring and summer 2003. Vol. 14.

6. Abedi Jafari Seed, Abed Zarandi (2009). Analysis on concept of trust in electronic city. The $2^{\text {nd }}$ international conference on E-municipality. Organization of municipalities and assistance of Ministry of Interiors.

7. Alalhesabi Mehran, Maryam Abbasi (2011). The role of favorable structure of city in achieving objectives of smart growth. National conference on sustainable development and urban civil activities.

8. Farid, Yadollah (1994). Geography and city knowledge. Tabriz: Publication of University of Tabriz.

9. Safaeipour Masoud, Zahra Abbasi (2014). An analysis on housing index in informal habitats (Northern Modares-1 locality, Dezful city). National conference on urbanism, urban administration and sustainable development. Tehran.

10. Nazari Mohammad, Fattah Aghazadfeh (2009). Electronic city from concepts to application- International conference on E-municipality- No 2.

11. Kiani Raeisi (2017). Analysis on physical- formative development of Fanouj city based on smart growth strategy. Journal of geography and planning, 21 (59), pp. 263280.

12. Heydari Soureshjani, Rasoul, Khalaji Nastaran (2018). Prioritization of smart growth indicators in line with revival of historical textures (Case study: Kashan city market). Journal of studies on urban zones, 3 (8).

13. Azani, Mehri, Parvaresh (2018). Comparison of land use pattern, sprawl and smart growth in sustainable development (Case study: Isfahan city Region No 11). Sent for correction by the jury. Journal of geography and ecological studies, 7 (25), pp. 57'72.

14. Statistical Center of Iran: www.amar.org.ir 


\section{Latin sources}

15. stalker, R.,(2000)," handbook of world. oxford university press".journal of management letters Azizi, M., (2003), Density in Urban Planning, University of Tehran Press

16. Cowan, Robert, (2005), The Dictionary Of Urbanism, Streetwise Press

17. Daniels, Tom and Deborah Bowers, (1997), Holding our Ground

18. Protecting America's FarmsEbbers, W. E , (2007), "Electronic government: Rethinking channel management strategies," Government Information Quarterly

19. Edwards, Mary and Haines, Anna, (2007), Evaluating Smart Growth: Implications for Small Communities, Journal of Planning Education and Research,vol.49

20. Flint, A., (2006), This Land: the Battle over Sprawl and the Future of American, the Johns Hopkins University Press, Baltimore

21. Grant, J., (2007), Encouraging Mixed Use in Practice. Incentives, Regulations, and Plans: The Role of States and Nation-states in Smart Growth Planning, Edited by Garret-Jan Knap, Hubert, A. Haccoû, Kelly J. Clifton and John W. Frece, Published by Edward Elgar Publishing

22. Odendaal, N. ,(2003), "Information and communication technology and local governance: understanding the difference between cities in developed and emerging economies", Computers, Environment and Urban Systems,vol. 27

23. Peiser, Richard. ( 2001). Decomposing Urban Sprawl ", Town Planning Review,vol, 72

24. Sahu, R., (2007), "Integrating internet, telephones, and call centers for delivering better quality e-governance to all citizens," Government Information Quarterly

25. The fifth annual A.T. Kearney, (2005), foreign policy globalization index, http://www. Atkearney.com

26. Walmsley, Anthony, (2006), Greenways: multiplying and diversifying in the 25.st century, Landscape and Urban Planning,vol.76

27. Ye lin et al, (2005)," What Is "Smart Growth?"-Really?" Journal of Planning Literature, vol.19

28. Ferraro, S. (2013). Smart Cities, Analysis of a Strategic Plan. (Master thesis).

29. Colldahi, C. Frey, S. \&Kelemen, J. E. (2013). Smart Cities: Strategic Sustainable Development for an Urban World. (Master thesis). Sweden: Karlskronauniversity.

30. Santana, M.V., Zhang, Q., Nachabe, M.H., Xie, X. and Mihelcic, J.R., 2017. Could smart growth lower the operational energy of water supply? A scenario analysis in Tampa, Florida, USA. Landscape and Urban Planning, 164, pp.99-108.

31. Pourahmad, A., Ziari, K., Hataminejad, H. and Pashabadi, S.P., 2018. Explanation of Concept and Features of a Smart City. BAGH-E NAZAR, 15(58), pp.5-26.

32. Christensen, Jack. 2013. On Compact Cities. Lincoln Planning Review 5 (1/2): $37-$ 42. 
33. Batisani, N. and Yarnal, B., 2011. Elasticity of capital-land substitution in housing construction, Gaborone, Botswana: Implications for smart growth policy and affordable housing. Landscape and urban planning, 99(2), pp.77-82.

34. Underwood, J.G., Francis, J. and Gerber, L.R., 2011. Incorporating biodiversity conservation and recreational wildlife values into smart growth land use planning. Landscape and Urban Planning, 100(1-2), pp.136-143.

35. McGarigal, K., Plunkett, E.B., Willey, L.L., Compton, B.W., DeLuca, W.V. and Grand, J., 2018. Modeling non-stationary urban growth: The SPRAWL model and the ecological impacts of development. Landscape and Urban Planning, 177, pp.178190.

36. Marinoni, O., Higgins, A., Coad, P. and Garcia, J.N., 2013. Directing urban development to the right places: Assessing the impact of urban development on water quality in an estuarine environment. Landscape and Urban Planning, 113, pp.62-77.

37. Chourabi, H. et al.(2012). Understanding smart cities: An integrative framework, Conference proceedings, 45th Hawaii International Conference on System Sciences. IEEE Computer Society, pp. 278-290.

38. Giffinger, Rudolf, Christian Fertner, Hans Kramar, Robert Kalasek, Nataša PichlerMilanovic, Evert Meijers (2007). Smart cities - Ranking of European medium-sized cities. Smart Cities, Vienna, Centre of Regional Science, pp. 5-21.

39. European Parliament(2014). Mapping smart cities in EU, Economic and Scientific policy, Policy department A, Publications office, available on: http:// www.Europarl.europa.eu/studies

40. Pazalos, K. and et al.(2012)."A Structured Methodology for Assessing and Improving e-services in Digital Cities", Telematics and Informatics, vol. 29, no. 1, pp. 121-136.

41. Pichler Milanovic, N.(2005). Transformation of Cities in Central and Eastern Europe: Towards Globalization, United Nations University Press, USA, pp. 90-103. 